\title{
Balther of Säckingen, Bishop of Speyer, Composer of Chants for St Fridolin ca. 970
}

\author{
David HILEY \\ Universität Regensburg, Institut für Musikwissenschaft \\ Universitätsstr. 31, D-93053 Regensburg, Deutschland \\ E-mail: david.hiley@ur.de
}

(Received: February 2015; accepted: April 2015)

\begin{abstract}
Balther of Säckingen was a remarkable scholar, writer and composer, who was born about 930, made bishop of Speyer in 970, and died in 986 or 987. Educated at the famous monastery in St. Gallen, he went as a wandering student in search of learning as far as North Spain. He had a special veneration for St Fridolin, founder of a convent in Säckingen. On his travels Balther found a copy of a Life of St Fridolin, memorized it, wrote it down on his return home, composed chants to be sung on the feast day of the saint, and sent both the Life (vita) and the chants (historia) to one of his former teachers at St. Gallen for approval. Balther says he composed them "per musicam artem", "according to the art of music". This paper tells how Balther's chants came to be composed and compares them with others in order to understand what was considered to be "musical art" around 970.
\end{abstract}

Keywords: Fridolin, Balther of Säckingen, ars musica, St. Gallen, office, historia, antiphon, responsory, mode

In the study of musical history it is still possible to discover unknown compositions, especially from the medieval period. This paper is about liturgical chants whose existence was known, but which could not be transcribed, because no source with staff notation had yet been discovered. There are certainly very many such chants, for scholarship has tended to concentrate on the earliest manuscripts, and the later Middle Ages, when composition by no means came to a halt, have been correspondingly neglected. And later manuscripts often preserve older compositions for which earlier sources are lost. The compositions discussed here were written about 970, yet the only known source with staff notation is dated 1586 . 
That is interesting in itself, but the background to the creation of these chants is more interesting still. So the first part of this article sketches the historical background, then the manuscript sources are described briefly, and finally the musical style of the melodies is discussed. What sort of chant were educated musicians writing in the late tenth century? Was it any different from "Gregorian chant" as we know it today from books like the Graduale Triplex or the Antiphonale Monasticum?

This paper concerns an Irish saint, Fridolin, who came to the town of Säckingen on the River Rhine between Basel and Lake Constance sometime in the early sixth century. More than three hundred years later a scholar from Säckingen, called Balther, wrote a biography of Fridolin and composed chants to be sung on his feast day, about the year 970. Balther prefaces his biography (known as a vita) with a letter of dedication to a former teacher, and in this preface we learn a great deal about Balther himself.

Many Irish missionaries came from the "emerald isle" to the continent of Europe. The most famous was Columbanus, who journeyed through France, past Lake Constance and down into Italy, where he died at Bobbio in the year 615. Near Lake Constance he left Gallus behind, whose fame as a hermit eventually led to the foundation of the famous monastery of St. Gallen. The influence of this missionary movement from Ireland should not be underestimated. Over 300 monasteries in the North French area alone can be attributed directly or indirectly to the Irish missionaries. They include such celebrated figures as Kilian of Würzburg and Virgilius of Salzburg, later venerated as saints.

Fridolin is not as famous as Columbanus. No writings or other evidence about his life and work survive from his own time, all we know about him is contained in Balther's vita. All relevant materials have been edited and explained in a splendid dissertation by Mechthild Pörnbacher (München), published in 1997. ${ }^{1}$ Dr. Pörnbacher was able to study a manuscript (now in Karlsruhe) with the liturgical chants notated in neumes, dating from the twelfth century. The neumes could not be transcribed or sung, until recently I found a source with the Fridolin chants in staff notation, written as late as 1586.

Balther tells us that Fridolin came from Ireland, first of all to Poitiers in France. Back in Roman times, Poitiers (Lemonum in Latin) was the city where St Hilary (Hilarius) had preached to the Pictones, and died in 367. But Fridolin found that Hilary's church had been destroyed long before, during the barbarian invasions of the fifth century. Nobody knew any more where the saint had been buried. Now Hilary appeared to Fridolin in a vision and revealed to him his resting place.

1. Mechthild Pörnbacher, Vita Sancti Fridolini. Leben und Wunder des heiligen Fridolin von Säckingen (Sigmaringen: Thorbecke, 1997). See also Pörnbacher's booklet St. Fridolin von Säckingen. Glaubensbote am Hochrhein (Lindenberg: Fink, 2001), which also contains a complete translation of Balther's Life of St Fridolin, and of his chants as well. 
Fridolin told the bishop of Poitiers, Hilary's remains were discovered, Fridolin and the bishop went to the Frankish King Clovis I (c. 466-c. 511, king 509-511), who agreed to support them in the rebuilding of Hilary's monastery. But Fridolin's labours were by no means at an end. Hilary once again appeared to him, and told him he must journey further, to the land of the Alemanni, where he would find an island in the middle of the River Rhine, and there he must preach the Word of God to the heathen. Fridolin set out, with a relic of St Hilary in his pouch. His exact route is not known, but can be surmised partly from the existence of churches dedicated to St Hilary, some of which were apparently founded by Fridolin. He probably journeyed along the Loire as far as Orléans, then across to Strasbourg, up the Rhine past Basel and over to Lake Geneva. Then he would have gone up the Rhône and the Oberalp pass to reach the headwaters of the Rhine, and downwards at last as far as Chur. There he asked the Bishop of Chur and his people if they knew of the island in the Rhine which had been promised to him by $\mathrm{St}$ Hilary. They did not, and indeed Fridolin had some distance still to go, following the Rhine down to Lake Constance, out of the lake into the river again, to find his island further downstream, about $50 \mathrm{~km}$ short of modern Basel. Here he founded a convent for religious women.

Balther was born in Säckingen, probably about 930, soon after the Hungarian raids on the area. His parents had had to flee from the invaders. (Luckily the relics of Fridolin could be saved.) As a boy Balther was sent to be educated at the famous monastery of St. Gall. In the dedicatory letter which begins his writings on Fridolin he names his teacher, Notker. This was one of the several Notkers who over the centuries distinguished themselves at St. Gall, Notker II, known as Notkerus Piperis Granum, "Notker Peppercorn". Unfortunately the money for Balther's education ran out and he had to leave the monastery school. For the next four years he travelled abroad as a poor wandering scholar, a "gyrovagus" as he calls himself. He says he wanted to consult "the masters of Western Gaul", and in fact his travels resembled somewhat those of the great Gerbert of Aurillac (later Pope Sylvester II), who had spent three years in Ripoll and Vic, learning from Greek, Arabic and Jewish scholarship. We don't know exactly where Balther stayed, but after four years he decided to return, "and see the familiar sights of my homeland". On the way home he came to a monastery near the Moselle, probably Saint-Avold between Metz and Saarbrücken, where Fridolin had founded a monastery dedicated to St Hilary. Balther told the abbot about his veneration for St Fridolin, and the abbot actually produced a Life of the Saint. Balther says: "At this I was greatly delighted, for I remembered the monastery of Säckingen lacked a Life of Fridolin; the book containing it was carried away when the monastery was laid waste by [Hungarian] pagans." Balther asked if he could borrow the book, but this wasn't allowed, and there was no parchment for making a copy. "So", says Balther, 
I sat down and recited it, and retained what I read in my memory. Sometimes I memorized the words with the sense, sometimes the sense alone without the construction of the precise words, so that I might be able to record what I read there for the memory of others.

Back in Säckingen, he writes down what he has remembered, and sends it to his old teacher Notker Peppercorn in St. Gall. And from his final words one may see why all this is important for the history of medieval chant. He writes:

Therefore, most devout father and teacher, commending myself to your invincible faith, I beseech you to determine whether this present booklet, with the responsories I have composed for the Feast of Saint Fridolin according to the art of music should be sung or destroyed in the flames ...

Balther was by no means a nonentity in his own time. In 970 he was appointed Bishop of Speyer, and became one of Emperor Otto I's advisors. There were close links between St. Gall and the imperial court, to which two of Balther's teachers, Ekkehard II and Notker Peppercorn paid visits. Perhaps they recommended Balther for promotion. A later writer of St. Gall, Ekkehard IV, remarking on this, says that Balther had been one of their best pupils, and he uses his nickname, Palzo: "Palzo Spirensis episcopus in loco nutritus, quo nemo fama ferente tunc eruditior." ("Balther, Bishop of Speyer, was brought up in our place and none more learned than he was known.")

What one would like to know is: what does Balther understand by the words "per musicam artem", "according to the art of music"? Admittedly, Balther may simply have been using a cliché here. He may have had in his mind a text which turns up in Carolingian times as a sort of preface to the gradual, the book containing chants for Mass. Here is one of the versions, from the ninth century:

\footnotetext{
Gregorius praesul meritis et nomine dignus

unde genus ducit summum conscendit honorem

qui renovans monumenta patrumque priorum

tum composuit hunc libellum musicae artis

scholae cantorum. ${ }^{2}$
}

Here Gregory is said to have "composed this book of musical art for the schola cantorum", the choir of singers. Another similar expression is to be found in a letter written around 820 by Helisachar, one of the advisors of Emperor Louis the 
Pious, about revising and correcting the chants to be sung during the Office. At the end of the letter Helisachar repeatedly refers to singing "after the manner of the melodic art" (secundum artis cantilenae modum), he speaks of chants composed "according to the elegant standard of the melodic art" (ad melodie artis normam decoremque compositi), and "the authority of this same [melodic] art" (eiusdem artis auctoritate). ${ }^{3}$ These techniques of delivering the chants of Mass and Office in the approved way may very well have been what Balther meant. Nevertheless, he had had a good education at the famous school of St. Gall, he was a bright boy who must have come into contact with music-theoretical ideas, concepts of what constituted "musical art" in the tradition of Boethius. Can we find anything in his Fridolin chants which reflects knowledge of music theory?

From the neumes of the Karlsruhe manuscript little can be learned in this respect, but the staff notation in the later source enables transcriptions to be made and a musical analysis to be undertaken. The Karlsruhe source (ms. GLA 65-429 in the Badische Landesarchiv) might be called a "Fridolin booklet", for it contains Balther's life of Fridolin, the liturgical office, and an office for St. Hilary as well (also composed by Balther? - unfortunately, no other source is known), but no other liturgical material. The later manuscript, by contrast, is a two-volume antiphoner, with Office chants for the whole year. It is now preserved in the Stiftsbibliothek of the Swiss Benedictine monastery of Einsiedeln, but it did not originate there. In fact its wanderings almost match those of Fridolin and Balther. It was copied by Nicolaus Holdermeyer, who was a canon in Beromünster from 1566, then moved down to Zurzach on the Rhine in 1584, was appointed provost in Zurzach in 1589, and returned to Beromünster as provost in 1601; he died there in 1613. Holdermeyer writes his name in the manuscript and dates it with the year 1586, when he was in Zurzach. So he would have brought it from Zurzach to Beromünster (in the hills north of Lucerne). From there it passed to the monastery of Rheinau (back on the Rhine, upstream from Säckingen and Zurzach) in 1624. After Rheinau had been secularized in 1864 it was taken to its present resting-place in Einsiedeln.

The neumes in the Karlsruhe manuscript and the staff-notation do not always agree exactly, and in three cases they notate different melodies. But most of the time there is no doubt about the correct transcription.

We shall come back to these niceties of musical composition in a moment, but it is worth digressing to say a word about the cycle of Latin texts. There are 27 altogether (Table 1).

3. From a letter to Archbishop Nidibrius of Narbonne, ca. 820, edition in Monumenta Germaniae Historica, Epistolae, vol. V (Berlin: Weidmann, 1899), 308-309; http:/www.dmgh.de/de/fs1/object/display/ bsb00000539_00315.html?sortIndex=040\%3A010\%3A0005\%3A010\%3A00\%3A00\&zoom=0.75 
Table 1 Historia de Sancto Fridolino

\begin{tabular}{|c|c|c|}
\hline & & Modus \\
\hline \multicolumn{3}{|l|}{ Ad Primas Vesperas } \\
\hline Antiphona ad Magnificat & Fridoline Christi confessor & 1 \\
\hline \multicolumn{3}{|l|}{ Ad Matutinum } \\
\hline Invitatorium & Confessorum regem adoremus & 4 \\
\hline \multicolumn{3}{|l|}{ In Primo Nocturno } \\
\hline Antiphona I & Beatus est iste homo & 1 \\
\hline Antiphona II & Orbis terre principibus & 2 \\
\hline Antiphona III & Tu es Domine quem iste sanctus & 3 \\
\hline \multirow[t]{2}{*}{ Responsorium I } & Beatus Fridolinus de regione Scotorum oriundus & \\
\hline & V. Iste sanctus Sophie mamillis suspensus & 4 \\
\hline \multirow[t]{2}{*}{ Responsorium II } & Sanctus iste patrie dulcedinem & \\
\hline & V. Ecce mundi contemptor & 1 \\
\hline \multirow[t]{2}{*}{ Responsorium III } & Vir iste a Deo probatus & 3 \\
\hline & V. Timore nudus caritate vestitus & \\
\hline \multicolumn{3}{|l|}{\begin{tabular}{|l|} 
In Secundo Nocturno \\
\end{tabular}} \\
\hline Antiphona IV & Sanctus Fridolinus quem ineffabiliter & 4 \\
\hline Antiphona V & Idem itaque sanctus bone voluntatis & 5 \\
\hline Antiphona VI & Hic inde progressus & 6 \\
\hline \multirow[t]{2}{*}{ Responsorium IV } & Sanctus Fridolinus in Pictavorum urbe & \\
\hline & V. Viribus infractis & 8 \\
\hline \multirow[t]{2}{*}{ Responsorium V } & Idem itaque vir iustus in eodem loco & \\
\hline & V. Fridolinus Dei famulus per lucrum & 1 \\
\hline \multirow[t]{2}{*}{ Responsorium VI } & Iste homo surdos cecos mutos & \\
\hline & V. Variis languoribus oppressos & 4 \\
\hline \multicolumn{3}{|l|}{ In Tertio Nocturno } \\
\hline Antiphona VII & Iste verus est Israelita & 7 \\
\hline Antiphona VIII & Cuius capiti Christus coronam & 8 \\
\hline Antiphona IX & O Fridoline confessor Christi & 1 \\
\hline \multirow[t]{2}{*}{ Responsorium VII } & Gloriosus iste confessor & \\
\hline & V. Cuius reliquias videlicet & \\
\hline \multirow{2}{*}{ Responsorium VIII } & Cum iam beati renovarentur festa Fridolini & 1 \\
\hline & V. Idem absque mora gaudet adesse & 2 \\
\hline \multirow[t]{2}{*}{ Responsorium IX } & Sancte Fridoline Deo plene & \\
\hline & V. Sexus feminei chorum ovantem & 1 \\
\hline \multicolumn{3}{|l|}{ Ad Laudes } \\
\hline Antiphona I & Cum beati renovarentur festa Fridolini & 2 \\
\hline Antiphona II & Hic itaque cum mutus existeret & 1 \\
\hline Antiphona III & Est illi datum colloquium & 8 \\
\hline Antiphona IV & Cuius corpus enorme & 4 \\
\hline Antiphona V & Sanus quippe est effectus & 5 \\
\hline Antiphona ad Benedictus & Nos Fridoline sanctissime & 1 \\
\hline \multicolumn{3}{|l|}{ Ad Secundas Vesperas } \\
\hline Antiphona ad Magnificat & Te Christi confessor venerabilis Fridoline & 1 \\
\hline
\end{tabular}


For First Vespers there is a spacious antiphon to frame the singing of the Magnificat. Most chants are assigned to the Night Office (or Vigils, Ad Matutinum). There is an Invitatory to frame the singing of Venite exultemus, and then the chants for three Nocturns. Each Nocturn has three psalms and three lessons; each psalm is framed by an antiphon, and each lesson is followed by a responsory; that makes nine antiphons and nine responsories. At daybreak Lauds is sung, which has five psalms with their attendant antiphons, and a larger antiphon for the canticle Benedictus. Finally there is another antiphon for Magnificat at Second Vespers.

Some of the Latin texts praise the good man and ask for his intercession, while for others Balther refers to events in Fridolin's life. The first responsory tells us where he came from: Beatus Fridolinus de regione Scotorum oriundus (Example 1).

The word "Scoti" originally denoted inhabitants of Ireland, who from the sixth century onward colonized the south-west of the area now called Scotland. Thus the monks of the Schottenkirche in Regensburg and its daughter-house the Schottenstift in Vienna were from Ireland.

The main task of telling about Fridolin's life and miracles is carried out by the lessons of the Night Office, taken from the vita. But the five psalm-antiphons at Lauds also form a narrative sequence, recounting how a man who is deaf, dumb and has no strength in his limbs, is healed when he comes to the shrine of St Fridolin on the saint's festival day. We can see from the final antiphon, for the Magnificat at Second Vespers, that the convent founded by Fridolin in Säckingen was for religious women or canonesses:
Te, Christi confessor, venerabilis Fridoline,
You, O confessor of Christ, cuius ovantes annua venerable Fridolin,
renovamus sollemnia, whose holy day we celebrate year for year with rejoicing, laudat virginum chorus the choir of virgins praises you ac simul omnis implorat clerus, quatenus clemens in celis fias intercessor pro nobis. and at the same time all the clerics beseech you that in heaven you will be a gentle intercessor for us.

(See also the final responsory, given below as Example 2)

The well-educated Balther would certainly have been able to set these texts to some of the traditional melodies of the Gregorian repertory, and sometimes his melodies do refer to the old ways of singing Office chants. We can see this in the first responsory, Beatus Fridolinus de regione Scotorum oriundus (see Example 1). Like all responsories, it is composed of two parts, the respond and the verse, after which the last part of the respond (from *Tam) is repeated. It is set in mode 4, ending on $\mathrm{E}$ (at "fulgebat") and ranging from $\mathrm{C}$ to $\mathrm{c}$. 
ExAmple 1 Balther of Säckingen, Historia Sancti Fridolini, Responsory Beatus Fridolinus de regione Scotorum
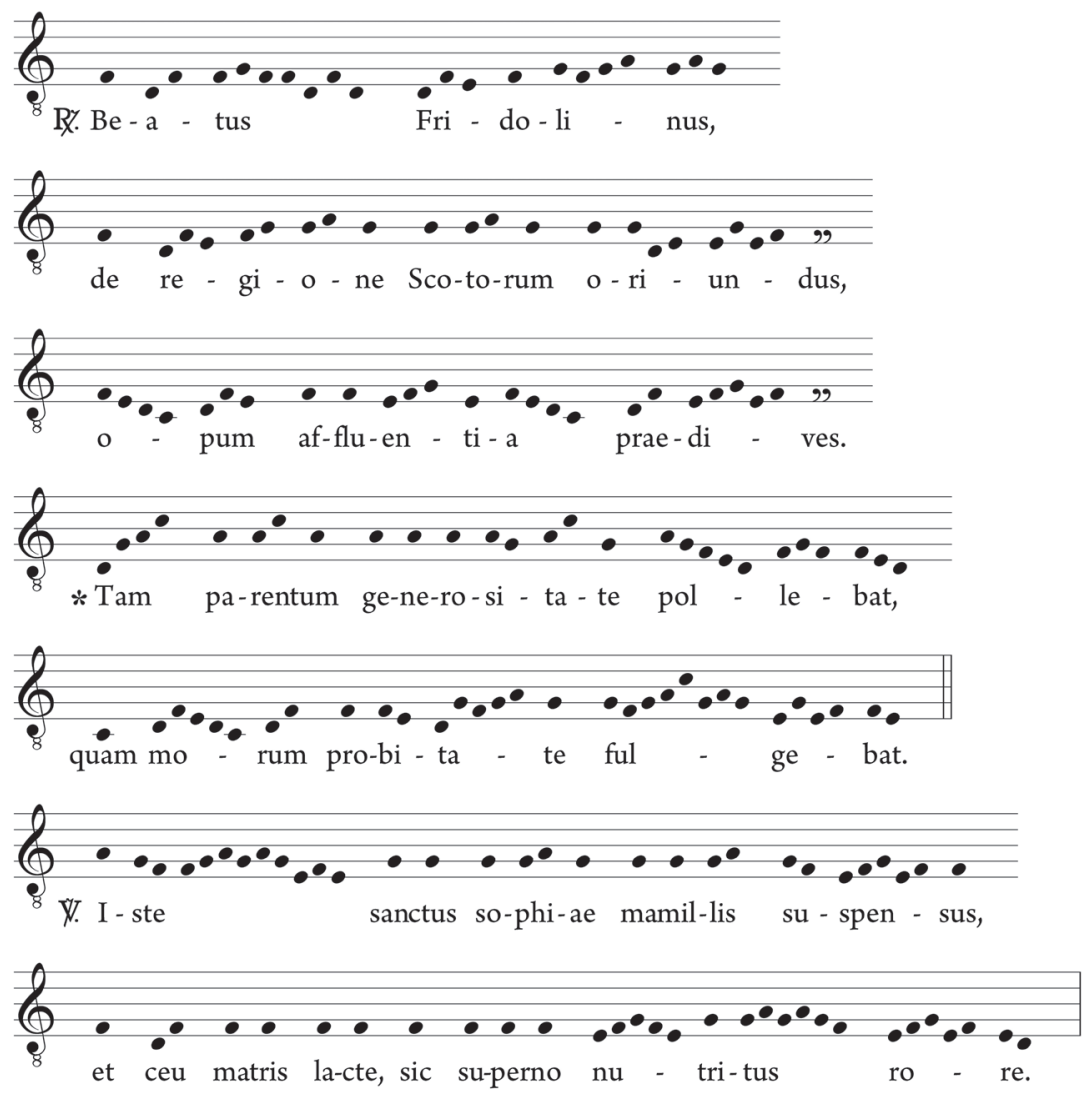

(Blessed Fridolin, sprung from the region of the Scots, was extremely rich in possessions. Just as he had great power by the gift of his parents, so he also shone by the probity of his behaviour.)

The first few notes use the most common opening for mode 4 responsories, and four of the five cadences of the respond are traditional. The whole of the verse is traditional. ${ }^{4}$ For the fourth phrase the respond steps outside mode 4, but not very far: the progression $\mathrm{D}-\mathrm{G}-\mathrm{a}-\mathrm{c}$ is typical for mode 3 melodies. (Mode 3 melodies also end on $\mathrm{E}$ but have a higher range, typically from $\mathrm{D}$ to $\mathrm{d}$.)

Very many responsories make use of typical melodic phrases which recur again and again in chants of the same mode. Responsories of mode 1 have typical

4. In the classic analysis of responsories by Walter Howard Frere, the first three cadences are labelled $\mathrm{G}^{1}$, $\mathrm{E}^{8}, \mathrm{E}^{5}$, the final one is the popular $\mathrm{E}^{1}$. See the Introduction to his Antiphonale Sarisburiense (London: Plainsong and Medieval Music Society, 1901-1924), 33-38; for the verse see ibid., 4. 
phrases, those of mode 2 have others, and so on. The phrases are associated with particular parts of the chant, some are opening gestures, some are used for middle periods, others lead to the final cadence. The verses have their own typical tones, one for each of the eight modes

We could say that here Balther is applying his knowledge of musical art by using the typical turns of phrase appropriately. That was the sort of "musical art" which Helisachar probably had in mind. However, at St. Gall Balther must have sung many other types of chant as well. Most famous nowadays among the newer compositions are the sequences of Notker Balbulus. Then there are the tropes composed by Tuotilo and others, and a new office for the patron of the monastery, St Gallus, was composed, apparently by the monk Ratpert. On 16 of November each year Balther would have sung another cycle, for St Otmar (who for part of his life was exiled onto a small island in the Rhine - not at Säckingen, but further upstream, at Stein). In all these cases Balther would have been confronted by a different sort of "musical art". It is not surprising, therefore, to find several compositions in the Fridolin cycle which no longer follow the old ways.

A prime example of new composition is the final responsory, Sancte Fridoline Deo plene, in mode 1 (Example 2). Like the final antiphon, quoted above, this last responsory alludes to the performance of the liturgy by both canonesses and clerics: Respond: "Holy Fridolin, suffused by God, commend us, who sing to you in sweet hymns, to your sweet patron St Hilary." Verse: "While the choir of women [literally, those of the female sex] praise you and the clerics stand joyfully in attendance upon the solemnities in your honour.'

Musically, we should notice how four words end, not with a falling cadence, but from below: "Sancte" (CD-D), "melodiis" (Ga-a), "ovantem" (CD-D) and "sollemniis" (Ga-a). Of the 25 words, 9 end on $\mathrm{D}$ and no less than 13 on a. Balther uses none of the old typical phrases for responsories in mode 1. Instead, the piece is held together in the strong grip of the key notes $\mathrm{D}$ and a, and by a few internal repetitions. The same turn of phrase is used for "nos tibi" and "commenda"; apart from the first few notes the same turn of phrase is used for "Sexus feminei" and "clerumque tuis". The melisma on "sancto" is made up of five note-groups, $5+$ $5+5+4+5$ notes, with the melodic pattern $\alpha-\beta-\alpha-\gamma-\beta$ '. That " $\beta$ " set of notes aGFGa can actually be found seven times in the whole piece (sometimes going over a syllable-change). Such features give a certain internal consistency to the chant, which we feel more on a subconscious level than rationally. The old typical melodic periods had a different function. They differentiate the internal structure of the single piece, but they link a responsory to all the others in the same mode right across the church year.

The emphasis on key notes in the new-style chants is related to new concepts of modal quality, reflected in the order of the chants in the Fridolin office. The nine 
ExAmple 2 Balther of Säckingen, Historia Sancti Fridolini,

Responsory Sancte Fridoline Deo plene
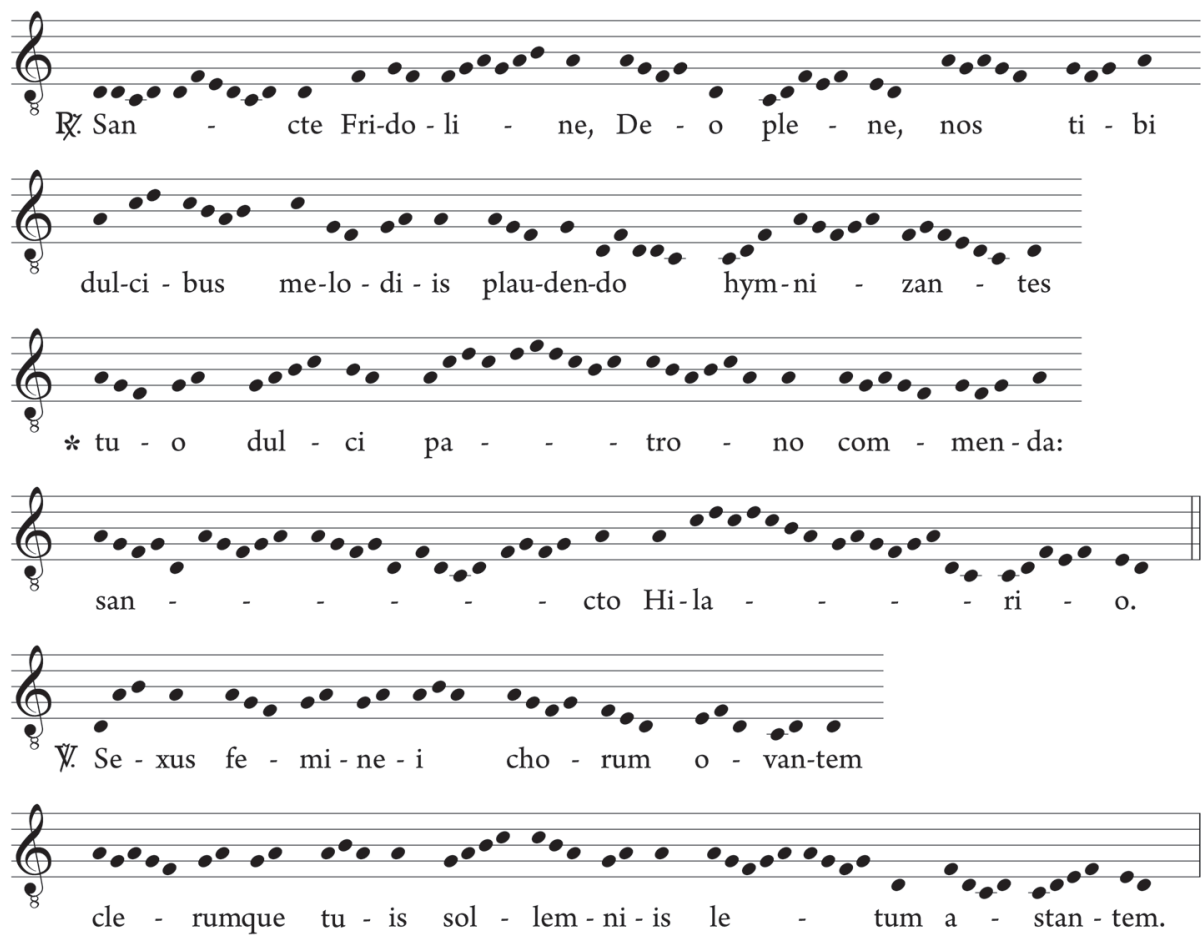

antiphons for the Night Office are set out in numerical modal order, in modes 1 to 8 and then mode 1 again (see Table). Balther is by no means the first composer to do this. At the end of the ninth century Stephen of Liège (who was bishop there 901-920) composed a numerical cycle of chants for the Holy Trinity which covered not only the antiphons but the responsories as well; and about the same time Hucbald, Abbot of St. Amand and a famous music theorist, composed a numerical set of antiphons for the Feast of St Peter's Chains. From the eleventh century onwards, practically every new office was organized in this way. One wonders if Balther, like other composers of new chants, was influenced by thoughts about the relationship between musical consonances and the harmony of the spheres, so common in music-theoretical writings of the Middle Ages. Did he read, for example, the Epistola de harmonica institutione by Regino of Prüm (ca. 900), which emphasizes the relationship between the system of the modes, the constituent elements of the tonal universe, and the divine order of the cosmos? A key passage from Regino reads: "In the eight modes not only is the whole harmony of the sacred melodies [harmonia spiritualis melodiae] contained and brought together, 
but also all natural song [omnis naturalis cantilena]". And this "all natural music" is none other than

that, which sounds neither on a musical instrument nor through human agency, nor requires the moving of the fingers, but that which, through divine inspiration [divinitus aspirata], and with Nature as teacher [natura docente], invents sweet melodies [dulces modulatur modos], which manifest themselves either in the movement of the spheres [in coeli motu] or in the human voice [in humana voce].

Writers on music of the generation after Balther, such as Bern and Hermannus on the Reichenau, who belong to the first half of the eleventh century, describe the eight modes in terms of their key notes, the most harmonious pitches, which are the finalis of course, the lower fourth, the upper fifth and the upper octave. And these become the notes which dominate the melodies of new South German office chants, the notes on which phrases and even individual words will most often end. Balther is very much in tune with this sort of melodic art, even if Bern and Hermannus provide more striking and ambitious examples in their offices for Ulrich of Augsburg (Bern), Afra of Augsburg, Magnus of St. Gall and Wolfgang of Regensburg (all by Hermannus). Even more impressive in this respect are the chants by Hildegard of Bingen.

We have seen an illustration of this in Balther's $9^{\text {th }}$ responsory. Here are some more examples, three antiphons and three responsories, starting with a 'classical Gregorian' example, and moving through Balther's less transitional pieces to the even more innovatory compositions of the eleventh century. All six examples are in mode 3.

Example 3a. Antiphon, Commune confessorum, Testamentum sempiternum ${ }^{5}$ - composed of four short phrases, here labelled $\alpha, \beta, \gamma$ and $\delta$.

Example $3 b$. Balther, Historia S. Fridolini, antiphon Tu es Domine - in two halves, uses phrases $\alpha, \beta$ and $\delta$ of the traditional Gregorian melody, then $\alpha$ and $\delta$ again with a new central period.

Example 3c. Bern of Reichenau, Historia S. Udalrici, antiphon Qui inter egregios - uses only the traditional opening; note two periods ending on the upper fifth $b$.

5. Antiphonen, eds László Dobszay - Janka Szendrei (Kassel etc.: Bärenreiter, 1999) (=Monumenta Monodica Medii Aevi 5), no. 3013. The monumental edition by Dobszay and Szendrei is organised according to melodic families, which make it easy to pick out 'classical Gregorian' compositions. 
Example 4a. Responsory, Commune apostolorum, Dum steteritis ante reges ${ }^{6}$ - restricted ambitus (D)E-c(d), traditional periods and verse, no period endings on $b$.

Example 4b. Balther, Historia S. Fridolini, responsory Vir iste - no traditional material; three endings on b; the ambitus extends up to e; melismas on "sparsit semina" and "Dei".

Example 4c. Historia S. Findani, responsory Agressus ad hoc districtionis the verse resembles the traditional tone, otherwise new material; six endings on b; two endings used three times each.

Example 3a Antiphon, Commune confessorum, Testamentum sempiternum
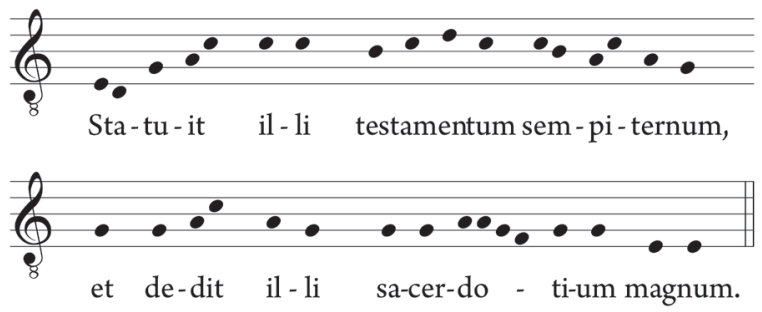

Example 3b Balther of Säckingen, Historia Sancti Fridolini, Antiphon Tu es Domine

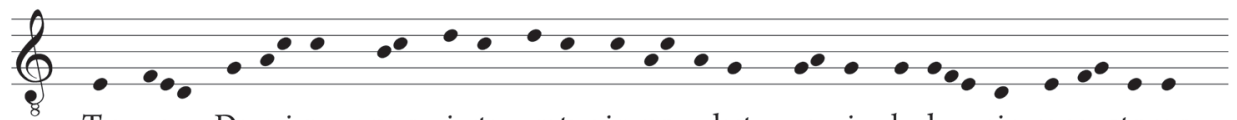

$\mathrm{Tu}$ es, Do-mi-ne, quem i-ste sanctus in-vo-cabat, su-i la-bo-ris susceptorem

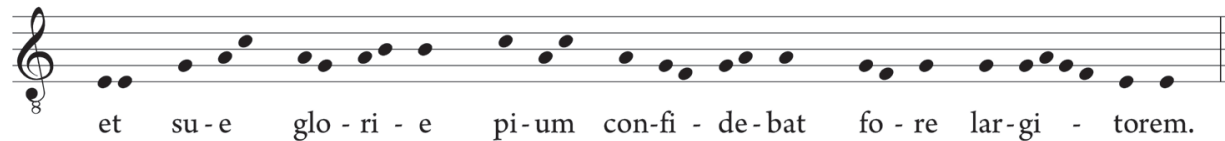

EXAmple 3c Bern of Reichenau, Historia Sancti Udalrici, Antiphon Qui inter egregios

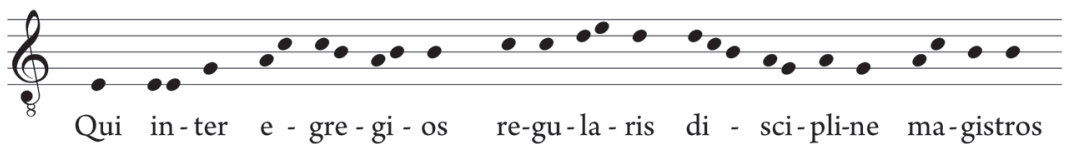

Qui in-ter e - gre-gi - os re-gu-la-ris di - sci-pli-ne ma-gistros

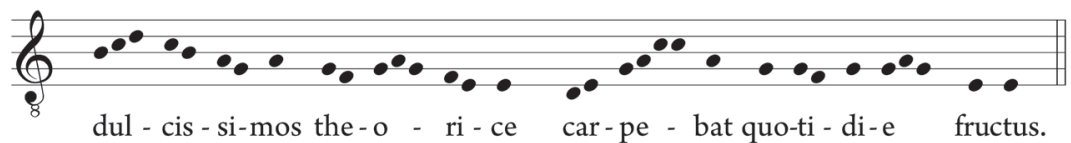

6. Responsories, eds László Dobszay - Janka Szendrei, with the collaboration of Beáta Meszéna (Budapest: Balassi Kiadó, 2013), no. 3029. This magnificent edition is also organised on musical principles. 
Example 4a Responsory, Commune apostolorum, Dum steteritis ante reges
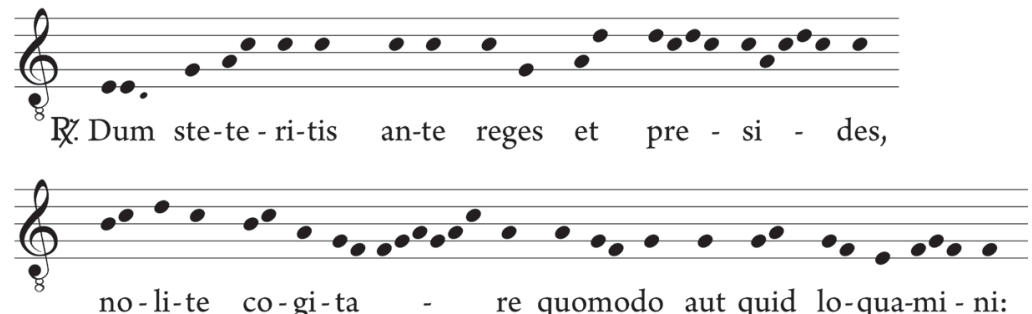

no-li-te co-gi-ta $\quad$ - re quomodo aut quid lo-qua-mi-ni:
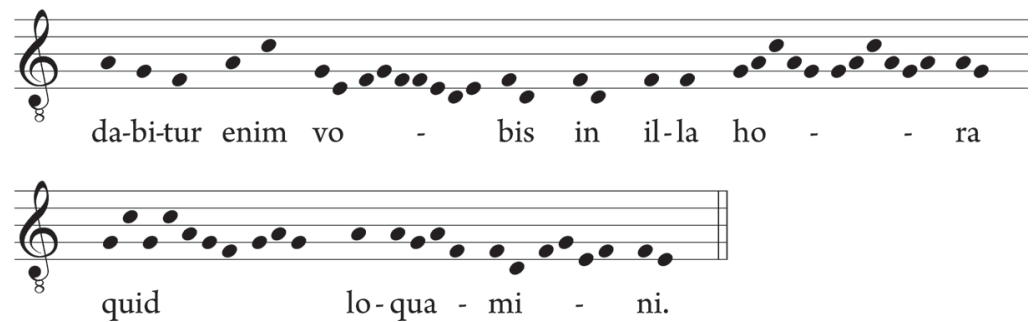

ExAmple 4b Balther of Säckingen, Historia Sancti Fridolini, Responsory Vir iste

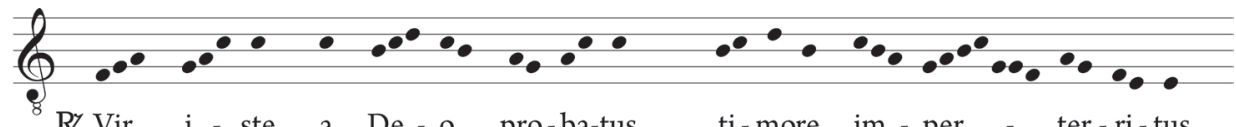

Ry. Vir i - ste a De - o pro-ba-tus, ti-more im-per - ter-ri-tus,
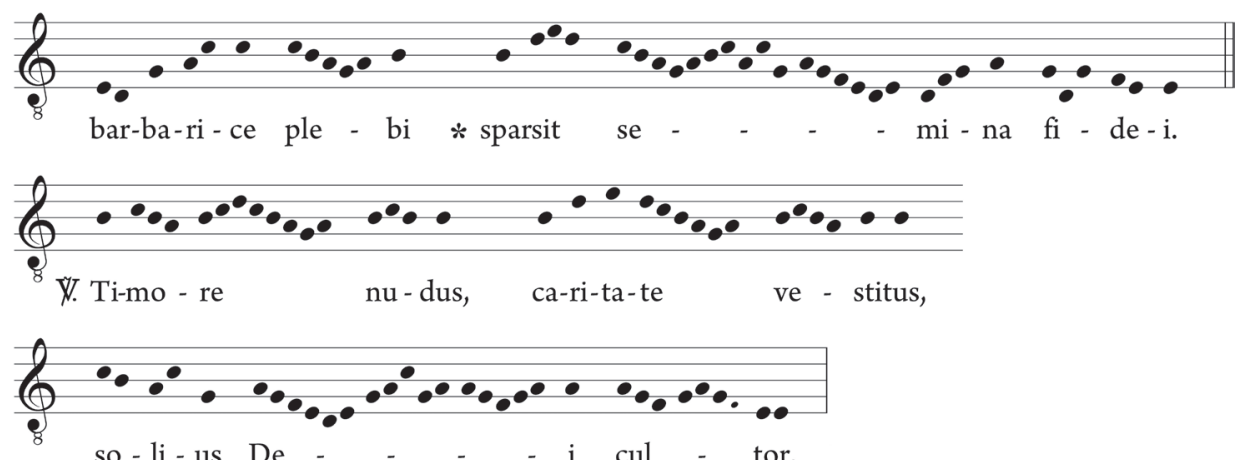
Example 4c Historia Sancti Findani, Responsory Agressus ad hoc districtionis
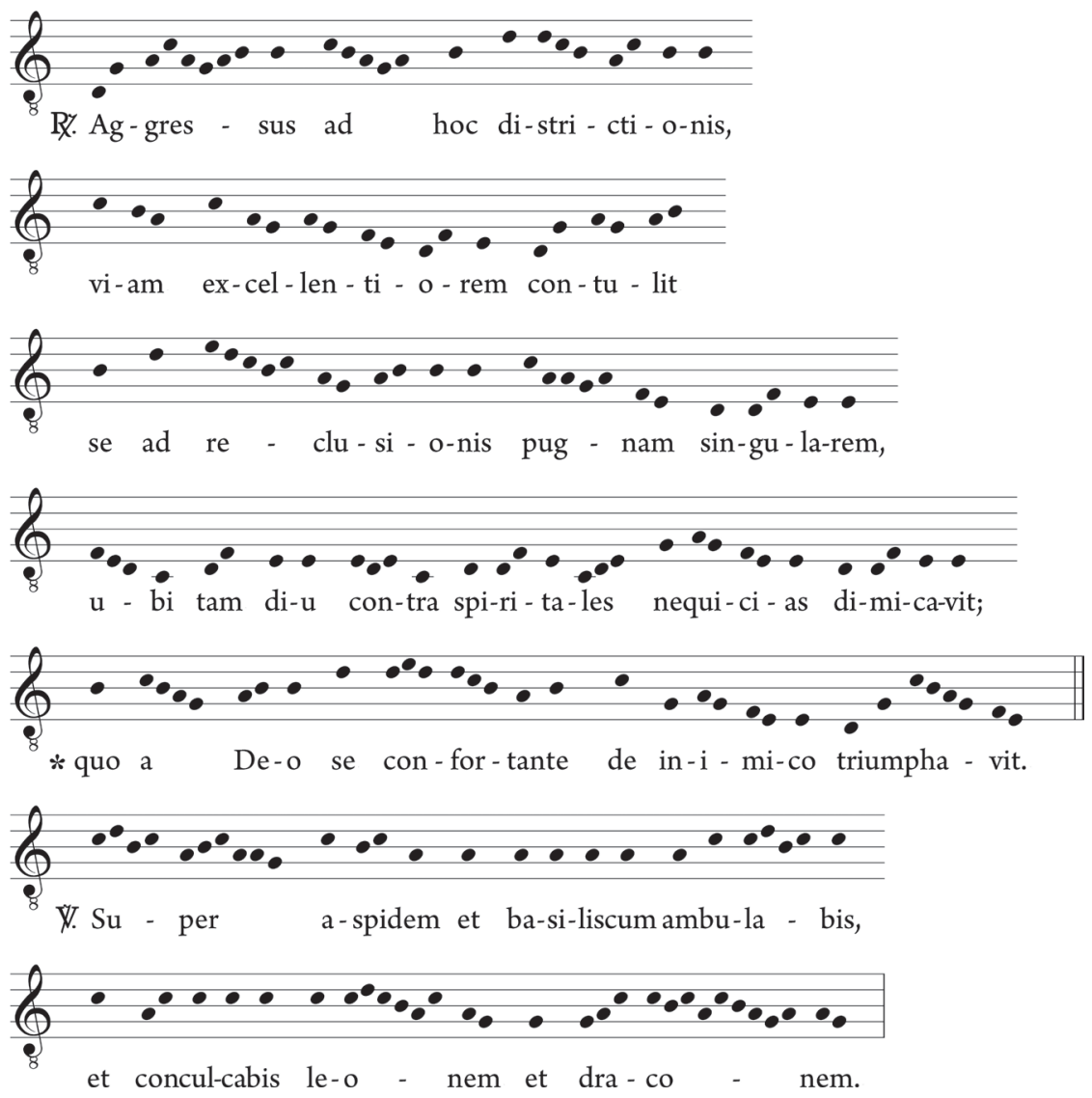

As related above, Balther sent his vita and historia of St Fridolin to Notker Peppercorn at St. Gall. I believe the old master would have been pleased at the mastery of "musical art" displayed by his former pupil. But fantasy apart, it is surely remarkable that we can reconstruct so much of the circumstances under which music was composed nearly 1050 years ago, and appreciate the technique and skill of its composer. Perhaps this skill played a part in his rise from penniless, wandering scholar to bishop of one of Germany's most important cathedrals. 